\title{
Persepsi Keamanan dan Sikap Terhadap Produk Berperan Dalam Pembelian Aktual Pasta Gigi Halal
}

\author{
Septi Kurnia Prastiwi \\ IAIN Surakarta \\ *septikurnia83@gmail.com
}

\begin{abstract}
Abstrak
Penelitian ini bertujuan untuk menganalisis beberapa variabel yang dapat meningkatkan pembelian actual (Actual purchase) pada produk pasta gigi Enzim . Beberapa variabel yang yang diduga dapat mempengaruhi pembelian aktual adalah persepsi keamanan, sikap dan niat pembelian. Penelitian ini menggunakan metode survei dengan populasi konsumen pasta gigi Enzim di Yogyakarta, dengan sampel sebanyak 100 responden, dengan pengambilan sampel purposive sampel, dan kuisioner dengan 15 indikator pertanyaan. Hasil uji validitas, reliabilitas, dan uji asumsi klasik mendukung untuk melanjutkan penelitian. Hasil uji path analysis mendapatkan hasil bahwa variabel Persepsi kemanan produk dan sikap berpengaruh signifikan terhadap niat pembelian dan pembelian actual. Niat pembelian juga berpengaruh signifikan terhadap pembelian actual. Untuk menguji apakah variabel niat pembelian dapat menjadi variabel mediator antara sikap dengan pembelian aktual, dibuktikan dengan hasil uji sobel test yang menemukan bahwa variabel niat pembelian signifikan sebagai variabel mediator.
\end{abstract}

Kata kunci: perceived safety, attitude, purchase intention, actual purchase

\section{Pendahuluan}

Pasta gigi sudah menjadi kebutuhan masyarakat selayaknya kebutuhan pokok, karena sudah menjadi kebiasaan untuk gosok gigi setiap mandi atau minimal $2 \mathrm{x}$ tiap hari. Hal tersebut memicu persaingan yang ketat antar perusahaan produk pasta gigi. Market share pasta gigi dikuasai oleh merek Pepsodent,

Tabel 1 Top Brand Index pasta gigi 2019

\begin{tabular}{|l|l|l|}
\hline \multicolumn{2}{|l|}{ PASTA GIGI } & \multicolumn{2}{l|}{} \\
\hline MERK & TBI & TOP \\
\hline Pepsodent & $68,3 \%$ & TOP \\
\hline Close Up & $10,7 \%$ & TOP \\
\hline Ciptadent & $9,5 \%$ & \\
\hline Formula & $7,2 \%$ & \\
\hline Sensodyne & $1,4 \%$ & \\
\hline
\end{tabular}




\section{Septi Kurnia Prastiwi}

Tabel diatas menunjukkan dari Frontier Consulting Group pada awal tahun 2019 (www.topbrand-award.com) menerapkan indicator kekuatan merek yang disebut Top Brand Index (TBI). Top Brand Index dirumuskan berdasarkan 3 variabel Mind Share, Market Share, Commitment Share. Untuk menentukan nilai dari ketiga variable, Frontier menggunakan tiga parameter yaitu top of mind awareness, merek pertama yang disebutkan oleh responden ketika mereka mendengar kategori produk, serta merek terakhir yang digunakan responden dan niat masa depan yaitu merek yang ingin digunakan responden dimasa depan. Data top brand index untuk kategori pasta gigi paling unggul adalah pepsodent diikuti brand close up, ciptadent, formula dan sensodyne.

Manusia banyak yang menggunakan zat pembersih (detergen) setiap harinya melalui pasta gigi. Berdasarkan hasil penelitian, detergen yang banyak digunakan pada pasta gigi termasuk salah satu zat yang merusak system pertahanan alami dalam mulut (air liur) yang disebut laktoperoksidase (LP-sistem). Padahal, 98 persen penyakit pada manusia modern masuk melalui makanan. Menurut Direktur PT Enzym Bioteknolgy Internusa yang memproduksi pasta gigi Enzim, LP-sistem merupakan system pertahanan tubuh terhadap mikro organisme yang secara alami terdapat pada rongga mulut. Berbagai penelitian menguatkan, persoalan gigi dan mulut itu terjadi karena air ludah atau saliva telah kehilangan fungsi pertahanannya. Berdasarkan hasil riset tersebut PT Enzym meluncurkan produk pasta gigi Enzim dengan diferensiasi utama yaitu tanpa detergen. Pasta gigi ini tidak hanya bermanfaat untuk membersihkan gigi tetapi juga untuk membersihkan rongga mulut dan mengembalikan fungsi air liur (www.marketing.co.id).

Pasta gigi enzim dipasarkan dengan segmen khusus, karena diferensiasi tanpa detergen sehingga membuat bahan bakunya mahal. Sebenarnya pasta gigi ditujukan untuk semua lapisan masyarakat, tetapi karena harga yang dibandrol lebih mahal dari pada pasta gigi pada umumnya, sehingga pangsa pasar nya cenderung ke premium. Akan tetapi strategi direferensiasi pasta gigi enzim yang tanpa detergen ternyata belum cukup untuk dapat menguasi market share. Bahkan di kelas yang sama masih kalah dengan merek Sensodyne yang sama menyasar kelas premium. Sensodyne berhasil menduduki urutan ke lima bersarkan data top brand index pada awal 2019.

Sehingga menjadi tantangan bagi perusahaan untuk dapat bersaing dengan merek lainnya. Sehingga perlu dievaluasi apakah persepsi masyarakat terhadap keamanan pasta gigi yang dikomunikasikan sebagai pasta gigi tanpa detergen, dan aman jika tertelan, serta telah bersertifikat halal MUI ini dapat dinilai baik oleh masyarakat. Sehingga akan membuat sikap yang positif terhadap produk pasta gigi enzim. Jika timbul persepsi keamanan produk (perceived safety) dan sikap (attitude) terhadap produk yang positif tentunya akan meningkatkan (purchase intention) niat pembelian dan aksi untuk melakukan pembelian (actual purchase). Semakin tinggi angka pembelian tentunya akan meningkatkan market share dan mempengaruhi nilai brand index.

Pasta gigi yang telah memiliki label halal juga penting untuk dikomunikasikan dalam promosi produk karena dapat meningkatkan loyalitas pada merek. Kesadaran produk halal berpengaruh signifikan terhadap brand loyalty dan dapat meningkatkan repurchase intention (Prastiwi \& Auliya, 2016)

Persepsi konsumen penting dalam mempengaruhi keputusan pembelian konsumsi makanan organic. Bagaimana konsumen memandang produk tersebut sangat penting karena akan menentukan niat pembelian dan mengkonsumsi produk, selanjutnya akan mengarah pada perilaku pembelian produk actual (Wee, Ariff, Zakuan, \& Tajudin, 2012).

Hasil peneitian menunjukan bahwa safety memberikan pengaruh lebih besar terhadap niat pembelian dalam konteks produk makanan organic, diikuti variable kesehatan, 


\section{Septi Kurnia Prastiwi}

environmental friendly, dan animal welfare (Wee et al., 2012). Persepsi masyarakat terhadap kemanan produk cukup penting diperhatikan oleh perusahaan karena dapat meningkatkan niat pembelian. Pasta gigi enzim mengkomunikasikan produk pasta giginya sebagai pasta gigi yang aman jika tertelan, tanpa detergen dan halal. Jika masyarakat berpersepsi bahwa pasta gigi aman untuk digunakan, maka tujuan perusahaan menjadikan keamanan produk dapat memberikan persepsi yang positif di masyarakat dan selanjurnya terkait attitude, sikap masyarakat terhadap produk. Selanjutnya apakah materi yang dikomunikasikan dalam promosi dapat menumbuhkan sikap yang positif pada masyarakat

Sikap masyarakat terhadap produk juga mempunyai peran penting dalam mempengaruhi perilaku pembelian terhadap produk. Hasil studi mendukung peran positif dari keyakinan konsumen, sikap dan norma subyektif yang berlaku sebagai factor utama yang mengarahkan konsumen untuk membeli produk personal care (Pandey \& Soodan, 2015). Adanya hubungan yang positif antara sikap terhadap niat pembelian, sikap adalah salah satu factor penting yang mempengaruhi niat konsumen untuk membeli produk halal (Rachbini, 2018). Sikap konsumen terhadap produk pasta gigi enzim yang sudah berlabel halal, dan sikap positif mengenai manfaat dan keunggulan produk dapat menjadi factor untuk menumbuhkan niat selanjutnya membeli produk tersebut.

Masyarakat yang memiliki niat untuk membeli produk besar kemungkinan untuk melakukan pembelian dimasa depan, hal ini diperkuat dengan hasil penelitian yang menemukan bahwa konsumen dengan niat pembelian tinggi akan berpangaruh positif terhadap pembelian produk herbal (Ismail \& Mohd Mokhtar, 2017). Tetapi hasil penelitian ini bertentangan dengan hasil penelitian bahwa niat pembelian tidak berpengaruh signifikan terhadap pembelian actual terhadap produk halal (Omar et.al, 2012)

Berdasarkan fenomena mengenai persaingan pada industry pasta gigi yang ketat, strategi perusahaan PT Enzym yang telah mengkomunikasikan bahwa produknya aman, tanpa detergen, aman jika tertelan dan halal tetapi performa produk masih belum masuk daftar lima besar top brand index kategori pasta gigi. Maka penelitian ini dilakukan untuk mengevaluasi permasalahan tersebut dengan menguji apakah perceived safety, dan attitude berpengaruh siginifikan terhadap purchase intention dan selanjutnya akan memediasi pengaruh terhadap actual purchase.

\section{Landasan Teori dan Pengembangan Hipotesis Persepsi Keamanan (Perceived safety)}

Lockie, menyatakan bahwa masalah keamanan pangan telah mendorong konsumen untuk mencari makanan yang lebih aman yang kualitas dan atributnya dijamin (Wee et al., 2012). Smith mendefinisikan keamanan pangan sebagai kondisi dan upaya mempertahankan kualitas sebuah makanan untuk mencegah kontaminasi. Keamanan pangan merupakan keprihatinan konsumen dengan makanan yang dihasilkan dari semprotan kimia, pupuk dan pengawet (Utami et al., 2017). Produk personal care apalagi pasta gigi tentu juga sangat memperhatikan unsur keamanan produk karena produk ini digunakan untuk membersihkan area gigi dan mulut dan bisa saja tertelan.

\section{Sikap (Attitude)}

Sikap adalah evaluasi melakukan perilaku tertentu yang melibatkan sikap terhadap obyek, seperti membeli produk menurut Blackwell dalam (Rachbini, 2018). Sikap terhadap perilaku, mengacu sejauh mana seseorang memiliki evaluasi atau penilaian yang menguntungkan atau tidak dapat diterima dari perilaku yang bersangkutan (Defranc et al., 


\section{Septi Kurnia Prastiwi}

2008). Fishben dan Aizen mendefisinikan sikap sebagai kecenderungan belajar untuk merespon secara konsisten baik atau tidak menguntungkan sehubungan dengan objek tertentu (Akilesh, 2015). Ajzen mengemukakan bahwa sikap terhadap perilaku ini ditentukan oleh keyakinan mengenai konsekuensi dari suatu perilaku atau secara singkat disebut keyakinan perilaku, keyakinan berkaitan dengan penilaian subjektif individu terhadap dunia sekitarnya, pemahaman individu mengenai diri dan lingkungannya dilakukan dengan cara menghubungkan antara perilaku tertentu dengan berbagai manfaat atau kerugian yang mungkin diperoleh apabila individu melakukan atau tidak melakukannya. Keyakinan ini dapat memperkuat sikap terhadap perilaku itu apabila berdasarkan evaluasi yang dilakukan individu diperoleh data bahwa perilaku itu dapat memberikan keuntungan baginya (Ramdhani et al., 2011)

\section{Niat Pembelian (Purchase Intention)}

Menurut Fishbein \& Ajzen pada TPB terencana mengasumsikan bahwa niat adalah perilaku, namun niat dipengaruhi oleh tiga konstruk yaitu sikap terhadap perilaku, norma subyektif, dan kontrol perilaku . Menurut TPB, niat mengacu pada ekspresi minat selama proses pengambilan keputusan dan juga dipengaruhi oleh sikap dan kepercayaan terhadap produk (Ismail \& Mokhtar, 2017). Intensi hendaknya berisikan niat melakukan, usaha mencoba, dan merencanakan suatu tindakan yang bertujuan (Machrus \& Purwono, 2010). Intensi adalah niat untuk melakukan dan terus melakukan perilaku tertentu (Ramdhani et al., 2011). Armitage dan Conner menyatakan bahwa niat diakui sebagai motivasi bagi individu untuk terlibat dalam perilaku tertentu. Niat pembelian dapat mempengaruhi keputusan pembelian pelanggan di masa depan (Omar et al., 2012).

\section{Pembelian Aktual (Actual purchase)}

Ajzen berpendapat bahwa perilaku adalah fungsi dari niat yang kompatibel dan persepsi control perilaku (Wee et al., 2012). Keputusan konsumen merupakan tindakan dalam memutuskan sebuah produk yang dianggap menjadi solusi dari kebutuhan dan keinginan konsumen tersebut. Proses inti dalam pengambilan keputusan konsumen adalah proses integrase yang digunakan untuk mengombinasikan pengetahuan untuk mengevaluasi dua atau lebih perilaku alternative dan memilih salah satu diantaranya (Peter \& Olson,2013)

Hasil penelitian menunjukkan bahwa safety memiliki efek yang terbesar terhadap niat pembelian dalam konteks produk makanan organic. Penelitian juga mengkonfirmasi bahwa persepsi keamanan adalah objek penting terhadap perilaku pembelian konsumen terhadap produk makanan organic (Wee et al., 2012). Kemanan pangan berpengaruh signifikan terhadap niat pembelian produk (utami et al., 2017). Hasil penelitian mengungkapkan bahwa kualitas dan keamanan produk penting dalam pembelian makanan konsumen (Kealesitse \& Kabama, 2012)

H1 : Persepsi produk aman (Perceived safety) berpengaruh signifikan terhadap purchase intention pasta gigi enzim.

H4: Persepsi produk aman (Perceived safety) berpengaruh signifikan terhadap actual purchase pasta gigi enzim

Hipotesis bahwa tidak ada pengaruh signifikan antara sikap individu terhadap produk personal care terhadap niat pembelian dan pembelian produk pada hasil penelitian ditolak, hal ini membuktikan bahwa sikap yang lebih positif terhadap suatu produk akan mengembangkan niat yang lebih positif terhadap produk dan akan menyebabkan pembelian. Sikap menjadi factor lain yang memainkan peran penting dalam mengubah individu menjadi konsumen yang 


\section{Septi Kurnia Prastiwi}

menguntungkan dan loyal. Hal ini merupakan sikap konsumen yang membantu dalam menentukan pembelian actual dari produk personal care Dalam hal ini pembelian produk personal care, sikap terhadap karakteristik produk, branding, pemasaran dan penetapan harganya dapat mempengaruhi pembelian (Pandey \& Soodan, 2015). Hasil penelitian menunjukaan bahwa sikap dan niat beli secara positif terkait dengan pembelian actual. Sikap terhadap produk herbal memainkan factor penting dalam mempengaruhi niat untuk produk herbal, sementara itu hubungan antara sikap dan pembelian actual juga konsisten dengan hasil penelitian sebelumnya, semakin positif sikap pelanggan terhadap produk herbal, semakin besar kemungkinan akan mempengaruhi pelanggan untuk membeli produk (Ismail \& Mokhtar, 2017). Sikap adalah factor penting dalam mempengaruhi niat konsumen dalam membeli produk halal karena mereka yang memiliki sikap positif tinggi tampaknya memiliki niat lebih besar untuk niat membeli produk halal (Rachbini, 2018). Sikap berpengaruh signifikan terhadap niat pembelian, jika mereka memiliki sikap positif akan mempengaruhi niat pembelian terhadap makanan halal, yang membuat mereka akan membeli lebih banyak dan lebih sering (Maichum, Parichatnon, \& Peng, 2017). Sikap menjadi factor lain yang memainkan peran penting yang mengubah individu menjadi konsumen yang menguntungkan dan loyal, sikap konsumen dapat menentukan pembelian actual pada produk personal care, dalam hal pembelian produk personal care sikap terhadap karakteristik produk, merek, program pemasaran dan harga dapat mempengaruhi pembelian (Akilesh, 2015)

H2: Sikap terhadap produk pasta gigi enzim berpengaruh signifikan terhadap purchase intention.

H3 : Sikap terhadap produk pasta gigi enzim berpengaruh signifikan terhadap actual purchase.

Perilaku pembelian actual pada produk organic berpengaruh signifikan disebabkan oleh niat pembelian terhadap produk tersebut. Hasil penelitian ini mendukung bahwa persepsi konsumen terhadap produk organic dipengaruhi oleh niat dan dapat meningkatkan terjadinya pembelian actual terhadap produk tersebut (Wee et al., 2012). Hasil penelitian juga menemukan bahwa niat beli berhubungan positif dengan pembelian actual, pelanggan dengan niat pembelian yang lebih tinggi akan secara positif mempengaruhi pelanggan untuk membeli produk herbal (Ismail \& Mokhtar, 2017)

H5: Purchase intention berpengaruh signifikan terhadap Actual Purchase

Kesimpulan pada penelitian membuktikan bahwa niat beli dapat memediasi pengaruh citra merek dan sikap konsumen terhadap keputusan pembelian (Nulufi \& Murwartiningsih, 2015).

H6: Purchase intention memediasi pengaruh sikap terhadap Actual Purchase

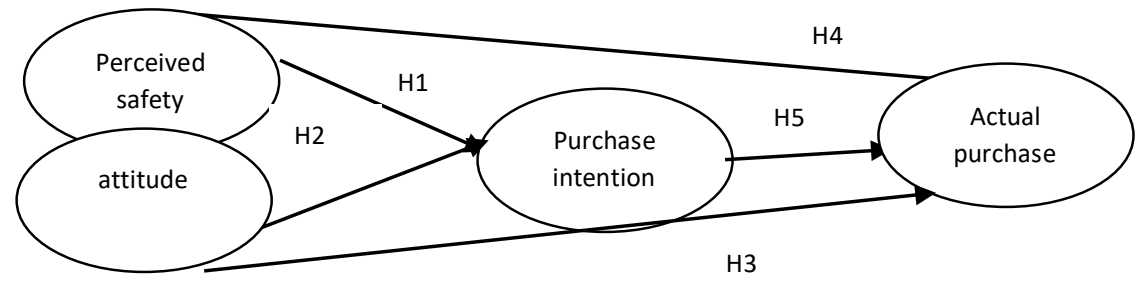

Gambar 1. Model Penelitian 


\section{Metode Penelitian}

Penelitian ini menggunakan pendekatan kuantitatif, dengan metode expost facto. Desain penelitian ini menggunakan desain descriptive dan regresi linier berganda . Pengujian data dengan menggunakan program SPSS 20. Penelitian ini adalah survey yang dilakukan pada konsumen pasta gigi Enzim di Yogyakarta. Populasi menurut Ferdinand (2014) adalah gabungan dari seluruh elemen yang berbentuk peristiwa, hal atau orang yang memiliki karakteristik yang serupa yang menjadi pusat perhatian seorang peneliti karena itu dipandang sebagai sebuah semesta penelitian. Populasi dalam penelitian ini adalah konsumen yang pernah membeli pasta gigi merek Enzim yang ada di area Yogyakarta. Sampel dalam penelitian ini diambil sebanyak 100 responden.

\section{Pembahasan}

\section{Uji Validitas dan Reliabilitas}

Reliabilitas adalah alat untuk mengukur kuisioner merupakan indikator dari variabel. SPSS memberikan fasilitas untuk mengukur reliabilitas dengan uji statistik Cronbach Alpha ( $\alpha$ ). Menurut Nunnally dalam (Ghozali;2013) suatu konstruk atau variabel dikatakan reliabel jika memberikan nilai Cronbach Alpha $>0.70$. Setelah semua indikator diuji, semua indikator memiliki nilai Cronbach Alpha > 0.70, sehingga semua indikator pertanyaan sudah reliabel.

Tabel 2. Reliability Statistics

\begin{tabular}{|l|c|}
\hline \multicolumn{1}{|c|}{ Variabel } & \multicolumn{2}{c|}{ Cronbach's Alpha } \\
\hline Persepsi Keamanan (Perceived safety) & 0,935 \\
\hline Sikap (Attitude) & 0,949 \\
\hline Niat Pembelian (Purchase Intention) & 0,971 \\
\hline Pembelian Aktual (Actual Purchase) & 0,984 \\
\hline
\end{tabular}

Berdasarkan hasil olah data dengan software SPSS didapatkan hasil bahwa ketiga variabel memiliki Cronbach Alpha > 0.70 sehingga semua variabel dalam penelitian ini reliabel.

Uji Validitas digunakan untuk mengukur valid atau tidaknya suatu kuisioner, suatu kuisioner dikatakan valid jika pertanyaan pada kuisioner mampu mengungkapkan sesuatu yang akan diukur oleh kuisioner tersebut (Ghozali; 2013). Validitas diuji dengan Confirmatory Factor Analysis (CFA). Alat uji lain yang yang digunakan mengukur tingkat interkorelai antar variabel dan dapat tidaknya dilakukan analisis faktor adalah Kaiser-Meyer-Olkin Measure of Sampling Adequacy (KMO MSA). Nilai KMO bervariasi dari 0 sampai dengan 1. Nilai yang dikehendaki harus $>0.50$ untuk dapat dilakukan analisis faktor.

Tabel 3. Rotated Component Matrix

\begin{tabular}{|c|c|c|c|c|c|c|c|}
\hline indikator & $\begin{array}{l}\text { Loading } \\
\text { factor }\end{array}$ & indikator & $\begin{array}{l}\text { Loading } \\
\text { factor }\end{array}$ & indikator & $\begin{array}{l}\text { Loading } \\
\text { factor }\end{array}$ & indikator & $\begin{array}{l}\text { Loading } \\
\text { factor }\end{array}$ \\
\hline PS1 & 0,693 & A1 & 0,917 & PI1 & 0,833 & AP1 & 0,878 \\
\hline PS2 & 0,764 & $\mathrm{~A} 2$ & 0,914 & PI2 & 0,755 & AP2 & 0,926 \\
\hline \multirow[t]{3}{*}{ PS3 } & 0,843 & & & PI3 & 0,785 & AP3 & 0,913 \\
\hline & & & & PI4 & 0,829 & AP4 & 0,921 \\
\hline & & & & PI5 & 0,869 & AP5 & 0,911 \\
\hline
\end{tabular}


Hasil rotasi faktor dengan metode varimax menunjukkan bahwa indikator Persepsi keamanan produk, sikap, niat pembelian dan pembelian actual mengelompok dengan nilai diatas 0,7. Jadi dapat disimpulkan bahwa semua konstruk variable memiliki unidimensionalitas atau dengan kata lain semua indikator valid.

\section{Uji Asumsi Klasik}

1) Uji Multikolinieritas

Uji multikolinieritas bertujuan untuk menguji apakah model regresi ditemukan adanya korelasi antar variabel bebas (independen) (Ghozali;2013).

Tabel 4. Coefficients ${ }^{\mathrm{a}}$

\begin{tabular}{|c|c|c|c|c|c|c|c|}
\hline \multirow[b]{2}{*}{ Model } & \multicolumn{2}{|c|}{$\begin{array}{c}\text { Unstandardized } \\
\text { Coefficients }\end{array}$} & \multirow{2}{*}{$\begin{array}{c}\begin{array}{c}\text { Standardize } \\
\mathrm{d}\end{array} \\
\text { Coefficients } \\
\text { Beta }\end{array}$} & \multirow[b]{2}{*}{$l$} & \multirow[b]{2}{*}{ Sig. } & \multicolumn{2}{|c|}{$\begin{array}{c}\text { Collinearity } \\
\text { Statistics }\end{array}$} \\
\hline & B & Std. Error & & & & Tolerance & VIF \\
\hline $\begin{array}{ll}1 & \text { (Constant } \\
& \end{array}$ & 2.539 & 1.895 & & 1.340 & .183 & & \\
\hline PS & .351 & .085 & .223 & 4.152 & .000 & .475 & 2.105 \\
\hline A & -.385 & .096 & -.167 & -4.017 & .000 & .792 & 1.263 \\
\hline PI & .881 & .060 & .823 & 14.728 & .000 & .438 & 2.283 \\
\hline
\end{tabular}

a. Dependent Variable: AP

Nilai Tolerance menunjukkan tidak ada variable independen yang memiliki nilai tolerance kurang dari 0.10 yang berarti tidak ada korelasi antar variabel independen yang nilainya lebih dari 95\%. Hasil Nilai Variance Inflation Factor (VIF) semua variabel independen nilai VIF tidak lebih dari 10. Sehingga tidak terjadi multikolinieritas antar variabel independen dalam model regresi.

\section{2) Uji Hesterokesdasititas}

Uji Heterokesdastisitas bertujuan menguji apakah dalam model regresi terjadi ketidaksamaan variance dari residual satu pengamatan ke pengamatan lain (Ghozali, 2013). Uji heteroskedastisitas dengan uji gletser, jika variabel independen signifikan secara statistik mempengaruhi variabel dependen, maka indikasi terjadi heteroskedastisitas. Hasil tampilan output SPSS dengan jelas menunjukkan bahwa variabel indpenden nilai sig. semua diatas 0,05 sehingga tidak ada yang signifikan mempengaruhi variabel dependen. Sehingga dapat disimpulkan bahwa model regresi tidak mengandung adanya heteroskedastisitas. 
Septi Kurnia Prastiwi

Tabel 5 Coefficients ${ }^{\mathrm{a}}$

\begin{tabular}{|c|c|c|c|c|c|c|}
\hline \multirow{2}{*}{\multicolumn{2}{|c|}{ Model }} & \multicolumn{2}{|c|}{$\begin{array}{c}\text { Unstandardized } \\
\text { Coefficients }\end{array}$} & \multirow{2}{*}{$\begin{array}{c}\text { Standardized } \\
\text { Coefficients } \\
\text { Beta }\end{array}$} & \multirow[b]{2}{*}{$\mathrm{t}$} & \multirow[b]{2}{*}{ Sig. } \\
\hline & & B & Std. Error & & & \\
\hline \multirow[t]{4}{*}{1} & (Constant) & 7.931 & 1.946 & & 4.075 & .000 \\
\hline & PS & .158 & .087 & .251 & 1.823 & .071 \\
\hline & A & -.116 & .098 & -.126 & -1.179 & .241 \\
\hline & PI & -.187 & .061 & -.436 & -3.045 & .053 \\
\hline
\end{tabular}

a. Dependent Variable: Abs_RES

3) Uji Normalitas

Uji normalitas bertujuan untuk menguji apakah dalam model regresi, variabel pengganggu atau residual memiliki distribusi normal (Ghozali; 2013). Uji statistik yang dapat digunakan untuk menguji normalitas residual adalah uji statistik non-parametrik Kolmogorov Smirnov (K-S). Uji K-S dilakukan dengan membuat hipotesis:

H0 : Data residual berdistribusi normal

HA: Data residual berdistribusi tidak normal

Tabel 6. One-Sample Kolmogorov-Smirnov Test

\begin{tabular}{|ll|r|}
\hline & & $\begin{array}{r}\text { Unstandardize } \\
\text { d Residual }\end{array}$ \\
\hline Normal Parameters & 100 \\
& Mean &, 0000000 \\
Most Extreme & Std. Deviation & 2,61094207 \\
Differences & Absolute &, 094 \\
& Positive &, 063 \\
Test Statistic & Negative &,- 094 \\
Asymp. Sig. (2-tailed) & &, 094 \\
\hline
\end{tabular}
a. Test distribution is Normal.
b. Calculated from data.
c. Lilliefors Significance Correction.

Besarnya nilai test statistik Kolmogorov -Smirnov adalah 0,94 dan signifikan pada 0.059 hal ini berarti $\mathrm{H} 0$ diterima yang berarti data residual berdistribusi normal

\section{Pembahasan hasil uji Hipotesis \\ Koefisien Determinasi}

Koefisien determinasi $\left(\mathrm{R}^{2}\right)$ pada intinya mengukur seberapa jauh kemampuan model dalam menerangkan variasi variabel dependen (Ghozali , 2013).

Tabel 7. Koefisien determinasi persamaan 1 Model Summary ${ }^{\mathrm{b}}$

\begin{tabular}{|l|c|r|r|r|}
\hline Model & R & R Square & $\begin{array}{c}\text { Adjusted R } \\
\text { Square }\end{array}$ & $\begin{array}{c}\text { Std. Error of } \\
\text { the Estimate }\end{array}$ \\
\hline 1 &, $823^{\mathrm{a}}$ &, 678 &, 673 & 2,636 \\
\hline
\end{tabular}

a. Predictors: (Constant), A, PS

b. Dependent Variable: PI 
Pada tabel koefisien model summary Adjusted R Square sebesar 0,673, yang berarti bahwa $67 \%$ variabel Attitude dan Perceived safety mempengaruhi purchase intention, dan $22,7 \%$ dipengaruhi variabel lain diluar model penelitian ini.

Tabel 8. Koefisien determinasi persamaan 2

Model Summary

\begin{tabular}{|l|c|r|r|r|}
\hline Model & R & R Square & $\begin{array}{c}\text { Adjusted R } \\
\text { Square }\end{array}$ & $\begin{array}{c}\text { Std. Error of } \\
\text { the Estimate }\end{array}$ \\
\hline 1 & $.932^{\mathrm{a}}$ & .869 & .865 & 1.555 \\
\hline
\end{tabular}

a. Predictors: (Constant), PI, A, PS

Pada tabel koefisien model summary Adjusted R Square sebesar 0,865, yang berarti bahwa $86 \%$ variabel Attitude,Perceived safety dan purchase intention mempengaruhi actual purchase, dan $14 \%$ dipengaruhi variabel lain diluar model penelitian ini.

\section{Uji Signifikansi Simultan}

Uji Statistik F pada dasarnya menunjukkan apakah semua variabel independen atau bebas yang dimasukkan dalam model mempunyai pengaruh secara bersama-sama terhadap variabel dependen (Ghozali, 2013)

Table 9. Uji F persamaan 1

ANOVA $^{\mathrm{a}}$

\begin{tabular}{|ll|r|r|r|r|r|}
\hline \multicolumn{2}{|l|}{ Model } & \multicolumn{1}{|c|}{$\begin{array}{c}\text { Sum of } \\
\text { Squares }\end{array}$} & df & Mean Square & F & Sig. \\
\hline 1 & Regression & 865.555 & 2 & 432.778 & 62.202 & $.000^{\mathrm{b}}$ \\
& Residual & 674.885 & 97 & 6.958 & & \\
& Total & 1540.440 & 99 & & & \\
\hline
\end{tabular}

a. Dependent Variable: PI

b. Predictors: (Constant), A, PS

Dari uji ANOVA atau $F$ Test didapat bahwa $F$ hitung sebesar 62,202 dengan probabilitas 0.000 , karena probabilitas jauh lebih kecil dari 0.05 , maka model regresi dapat digunakan untuk memprediksi variabel dependen purchase intention.

Tabel 10. Uji $F$ persamaan 2

ANOVA $^{\mathrm{a}}$

\begin{tabular}{|ll|r|r|r|r|r|}
\hline \multicolumn{2}{|l|}{ Model } & \multicolumn{1}{|c|}{$\begin{array}{c}\text { Sum of } \\
\text { Squares }\end{array}$} & df & Mean Square & F & Sig. \\
\hline 1 & Regression & 1534.135 & 3 & 511.378 & 211.555 & $.000^{\mathrm{b}}$ \\
& Residual & 232.055 & 96 & 2.417 & & \\
& Total & 1766.190 & 99 & & & \\
\hline
\end{tabular}

a. Dependent Variable: AP

b. Predictors: (Constant), PI, A, PS 
Dari uji ANOVA atau F Test didapat bahwa $F$ hitung sebesar 211,55 dengan probabilitas 0.000 , karena probabilitas jauh lebih kecil dari 0.05 , maka model regresi dapat digunakan untuk memprediksi variabel dependen actual purchase.

\section{Uji Signifikansi Parameter Individual}

Uji statistic t pada dasarnya menunjukkan seberapa jauh pengaruh satu variabel penjelas/ independen secara individual dalam menerangkan variasi variabel dependen.

Tabel 11. Uji Statistik T Persamaan 1 Coefficients $^{\mathrm{a}}$

\begin{tabular}{|c|c|c|c|c|c|c|}
\hline \multirow{2}{*}{\multicolumn{2}{|c|}{ Model }} & \multicolumn{2}{|c|}{$\begin{array}{c}\text { Unstandardized } \\
\text { Coefficients }\end{array}$} & \multirow{2}{*}{$\begin{array}{c}\begin{array}{c}\text { Standardized } \\
\text { Coefficients }\end{array} \\
\text { Beta }\end{array}$} & \multirow[b]{2}{*}{$\mathrm{t}$} & \multirow[b]{2}{*}{ Sig. } \\
\hline & & $\mathrm{B}$ & Std. Error & & & \\
\hline \multirow[t]{3}{*}{1} & (Constant) & 11.296 & 3.004 & & 3.761 & .000 \\
\hline & PS & .948 & .107 & .644 & 8.900 & .000 \\
\hline & $\mathrm{A}$ & .459 & .156 & .213 & 2.949 & .004 \\
\hline
\end{tabular}

a. Dependent Variable: PI

Tabel 12. Uji Statistik T Persamaan 2

Coefficients $^{\mathrm{a}}$

\begin{tabular}{|c|c|c|c|c|c|c|}
\hline \multirow{2}{*}{\multicolumn{2}{|c|}{ Model }} & \multicolumn{2}{|c|}{$\begin{array}{c}\text { Unstandardized } \\
\text { Coefficients }\end{array}$} & \multirow{2}{*}{$\begin{array}{c}\text { Standardized } \\
\text { Coefficients } \\
\text { Beta }\end{array}$} & \multirow[b]{2}{*}{ 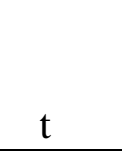 } & \multirow[b]{2}{*}{ Sig. } \\
\hline & & B & Std. Error & & & \\
\hline \multirow[t]{4}{*}{1} & (Constant) & 2.539 & 1.895 & & 1.340 & .183 \\
\hline & PS & .351 & .085 & .223 & 4.152 & .000 \\
\hline & A & .385 & .096 & .167 & 4.017 & .000 \\
\hline & PI & .881 & .060 & .823 & 14.728 & .000 \\
\hline
\end{tabular}

a. Dependent Variable: AP

Hasil pengujian hipotesis adalah sebagai berikut:

\section{Hipotesis 1: Persepsi produk aman (Perceived safety) berpengaruh signifikan terhadap purchase intention pasta gigi enzim.}

Berdasarkan tabel diatas dapat diketahui bahwa nilai T hitung variabel Perceived Safety sebesar 8.900 dan nilai $\mathrm{T}$ tabel untuk $\mathrm{N}=100$ dengan tingkat kesalahan 5\% adalah 1,98. Angka tersebut menunjukkan Thitung > Ttabel dan nilai Sig 0.000 lebih kecil dari 0,05. Ho ditolak pada tingkat kepercayaan $95 \%$, artinya bahwa terdapat pengaruh yang signifikan antara Perceived safety terhadap purchase intention. Pasta gigi Enzim merupakan green product,tanpa kandungan detergen serta sudah berlogo halal sehingga aman untuk digunakan, hal tersebut mendukung persepsi keamanan produk cukup penting untuk dapat mempengaruhi niat pembelian pada produk pasta gigi. Produk pasta gigi merupakan produk yang digunakan seharihari sehingga unsur keamanan produk juga menjadi pertimbangan konsumen. 
Hipotsesis 2: Sikap terhadap produk pasta gigi enzim berpengaruh signifikan terhadap purchase intention.

Berdasarkan tabel diatas dapat diketahui bahwa nilai T hitung variabel sikap (Attitude) sebesar 2.949 dan nilai T tabel untuk $\mathrm{N}=100$ dengan tingkat kesalahan 5\% adalah 1,98. Angka tersebut menunjukkan Thitung> Ttabel dan nilai Sig 0.004 lebih kecil dari 0,05. Ho ditolak pada tingkat kepercayaan $95 \%$, artinya bahwa terdapat pengaruh yang signifikan antara sikap (Attitude) terhadap purchase intention. Konsumen yang bersikap positif dan baik terhadap produk pasta gigi yang ramah lingkungan akan mempengaruhi niat pembelian pada produk tersebut.

\section{Hipotesis 3: Sikap terhadap produk pasta gigi enzim berpengaruh signifikan terhadap actual purchase.}

Berdasarkan tabel persamaan 2 diatas dapat diketahui bahwa nilai $\mathrm{T}$ hitung variabel sikap (Attitude) sebesar 4.017 dan nilai $\mathrm{T}$ tabel untuk $\mathrm{N}=100$ dengan tingkat kesalahan 5\% adalah 1,98. Angka tersebut menunjukkan Thitung > Ttabel dan nilai Sig 0.000 lebih kecil dari 0,05. Ho ditolak pada tingkat kepercayaan $95 \%$, artinya bahwa terdapat pengaruh yang signifikan antara sikap (Attitude) terhadap actual purchase. Jika konsumen memiliki sikap yang positif dan baik terhadap produk pasta gigi akan mempengaruhi keputusan pembelian actual produk.

\section{Hipotesis 4: Persepsi kemanan pada produk pasta gigi enzim berpengaruh signifikan terhadap actual purchase.}

Berdasarkan tabel persamaan 2 diatas dapat diketahui bahwa nilai $\mathrm{T}$ hitung variabel sikap (Attitude) sebesar 4.152 dan nilai $\mathrm{T}$ tabel untuk $\mathrm{N}=100$ dengan tingkat kesalahan 5\% adalah 1,98. Angka tersebut menunjukkan Thitung> Ttabel dan nilai Sig 0.000 lebih kecil dari 0,05. Ho ditolak pada tingkat kepercayaan $95 \%$, artinya bahwa terdapat pengaruh yang signifikan antara persepsi kemanan produk (safety prodcut) terhadap actual purchase. Persepsi kemanan produk pasta gigi yang merupakan green product,tanpa kandungan detergen serta sudah berlogo halal sehingga aman untuk digunakan, hal tersebut mendukung persepsi keamanan produk cukup penting untuk dapat mempengaruhi pembelian aktual pada produk pasta gigi.

\section{H5: Purchase intention berpengaruh signifikan terhadap Actual Purchase}

Berdasarkan tabel persamaan 2 diatas dapat diketahui bahwa nilai $\mathrm{T}$ hitung variabel niat pembelian (purchase intention) sebesar 14.728 dan nilai $\mathrm{T}$ tabel untuk $\mathrm{N}=100$ dengan tingkat kesalahan 5\% adalah 1,98. Angka tersebut menunjukkan Thitung> Ttabel dan nilai Sig 0.000 lebih kecil dari 0,05. Ho ditolak pada tingkat kepercayaan 95\%, artinya bahwa terdapat pengaruh yang signifikan antara niat pembelian (purchase intention) terhadap actual purchase. Niat konsumen untuk membeli produk pasta gigi yang aman, green product dan berlogo halal akan mendorong konsumen untuk melakukan pembelian actual pada produk pasta gigi Enzim. 


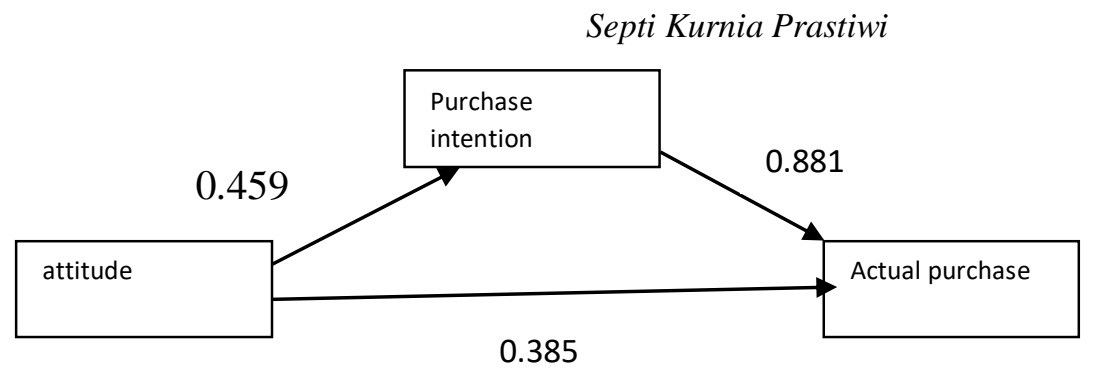

Gambar 2. analisis Jalur 1

Hasil analisis jalur menunjukaan bahwa Attitude dapat berpengaruh langsung ke Actual Purchase, dan dapat juga bepengaruh tidak langsung yaitu dari Attitude ke Purchase intention sebagai intervening lalu ke Actual purchase. Besarnya pengaruh langsung adalah 0.385 , sedangkan besarnya pengaruh tidak langsung yaitu; $0.459 \mathrm{x} 0.881=0.4043$. Pengaruh mediasi yang ditunjukkan oleh perkalian koefisien p2 dan p3 sebesar 0.4043 signifikan atau tidak diuji dengan sobel test, sebagai berikut:

$$
\begin{aligned}
& \mathrm{Sp} 2 \mathrm{p} 3=\sqrt{\mathrm{p}} 3^{2} \mathrm{Sp} 2^{2}+\mathrm{p}^{2} \mathrm{Sp} 3^{2}+\mathrm{Sp} 2^{2} \mathrm{Sp} 3^{2} \\
& \mathrm{Sp} 2 \mathrm{p} 3=\sqrt{ }(0.881)^{2}(0.156)^{2}+(0.459)^{2}(0.060)^{2}+(0.156)^{2}(0.060)^{2} \\
& \mathrm{t}=\mathrm{p} 2 \mathrm{p} 3=2.88 \\
& \mathrm{sp} 2 \mathrm{p} 3
\end{aligned}
$$

Nilai t hitung $=2.88$ lebih besar dari t tabel dengan tingkat signifikansi 0.05 yaitu sebesar 1.98, sehingga dapat disimpulkan bahwa koefisien mediasi 0.4043 signifikan, yang berarti ada pengaruh mediasi. Variabel purchase intention signifikan memediasi antara variabel attitude terhadap actual purchase.

Pengaruh Attitude terhadap pembelian actual lebih besar pengaruhnya jika melalui mediasi niat pembelian terhadap produk pasta gigi Enzim. Jika sikap konsumen terhadap produk positif dan baik akan menimbulkan niat untuk membeli produk pasta gigi Enzim yang aman dan berlogo halal, selanjutnya akan mempengaruhi perilaku pembelian actual pasta gigi tersebut.

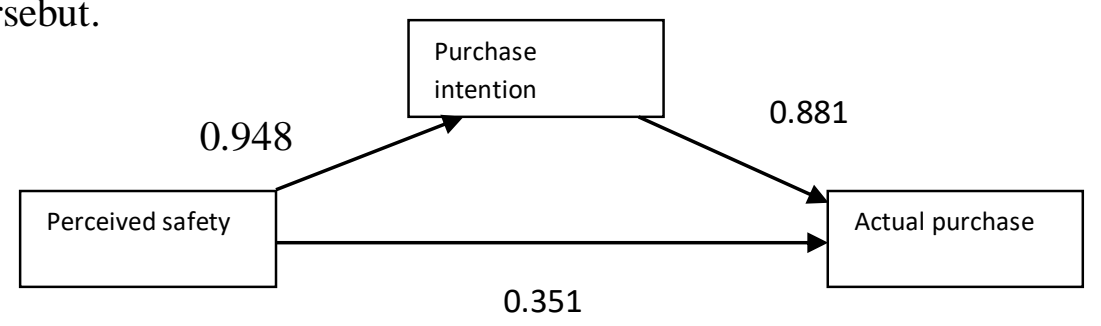

Gambar 3. analisis Jalur 2

Hasil analisis jalur menunjukaan bahwa Perceived safety dapat berpengaruh langsung ke Actual Purchase, dan dapat juga bepengaruh tidak langsung yaitu dari perceived safety ke Purchase intention sebagai intervening lalu ke Actual purchase. Besarnya pengaruh langsung adalah 0.351, sedangkan besarnya pengaruh tidak langsung yaitu; 0.948x $0.881=0.835$. Pengaruh mediasi yang ditunjukkan oleh perkalian koefisien p2 dan p3 sebesar 0.835 signifikan atau tidak diuji dengan sobel test, sebagai berikut:

$$
\begin{aligned}
& \mathrm{Sp} 2 \mathrm{p} 3=\sqrt{\mathrm{p}} 3^{2} \mathrm{Sp} 2^{2}+\mathrm{p}^{2} \mathrm{Sp} 3^{2}+\mathrm{Sp} 2^{2} \mathrm{Sp} 3^{2} \\
& \mathrm{Sp} 2 \mathrm{p} 3=\sqrt{ }(0.881)^{2}(0.107)^{2}+(0.948)^{2}(0.060)^{2}+(0.107)^{2}(0.060)^{2} \\
& \mathrm{t}=\underline{\mathrm{p} 2 \mathrm{p} 3}=7.58
\end{aligned}
$$


sp2p3

Nilai t hitung $=7.58$ lebih besar dari t tabel dengan tingkat signifikansi 0.05 yaitu sebesar 1.98, sehingga dapat disimpulkan bahwa koefisien mediasi 0.835 signifikan, yang berarti ada pengaruh mediasi. Variabel purchase intention signifikan memediasi antara variabel perceived safety terhadap actual purchase.

Jika persepsi konsumen terhadap kemanan produk positif dan baik akan menimbulkan niat untuk membeli produk pasta gigi Enzim yang aman dan berlogo halal, selanjutnya akan mempengaruhi perilaku pembelian actual pasta gigi tersebut. Tetapi dalam penelitian ini variabel purchase intention signifikan memediasi hubungan antara perceived safety terhadap actual purchase tidak diujikan karena peneliti belum menemukan hasil penelitian sebelumnya yang mendukung hipotesis.

\section{Kesimpulan}

Kesimpulan dalam penelitian ini menunjukkan bahwa variabel keamanan produk ( perceived safety) berpengaruh siginifikan terhadap niat pembelian (purchase intention) pasta gigi Enzim. Hasil uji hipotesis menunjukkan bahwa sikap (attitude) berpengaruh positif dan signifikan terhadap niat pembelian (purchase intention) pasta gigi Enzim. Hasil uji hipotesis menunjukkan bahwa sikap (attitude) berpengaruh positif dan signifikan terhadap pembelian aktual (actual purchase) pasta gigi Enzim. Variabel keamanan produk ( perceived safety) berpengaruh siginifikan terhadap pembelian aktual (actual purchase) pasta gigi Enzim.Hasil uji hipotesis menunjukkan bahwa niat pembelian (purchase intention) berpengaruh positif dan signifikan terhadap pembelian aktual (actual purchase) pasta gigi Enzim. Hasil uji sobel test menunjukkan bahwa purchase intention dapat memediasi hubungan antara attitude dengan actual purchase.

Perusahaan penting untuk mengkomunikasikan, mengedukasi masyarakat, dan mencantumkan materi dalam promosi bahwa produk pasta gigi aman untuk digunakan, kandungan bahan pasta gigi aman jika tertelan, dan merupakan produk yang ramah lingkungan serta sudah berlogo halal, sehingga konsumen akan bersikap positif dan persepsi keamanan produk juga baik, hal tersebut dapat meningkatkan perilaku pembelian dan selanjutnya dapat meningkatkan penjualan. Pada penelitian berikutnya diharapkan dapat menggunakan variable lain yang dapat mempengaruhi pembelian actual dan responden yang lebih luas.

\section{Daftar Pustaka}

Defranc, A., Van Den Broucke, S., Leroy, R., Hoppenbrouwers, K., Lesaffre, E., Martens, L., ... Declerck, D. (2008). Measuring oral health behaviour in Flemish health care workers: An application of the theory of planned behaviour. Community Dental Health, 25(2), 107-114. https://doi.org/10.1922/CDH_2120VandenBroucke08

Ferdinand Augusty. 2014. Metode Penelitian Manajemen. .Semarang: Badan Penerbit Universitas diponegoro.

Ghozali, I. (2013). Aplikasi Analisis Multivariate dengan Program SPSS edisi 7. Semarang: Badan Penerbit Universitas Diponegoro.

Ismail, S., \& Mohd Mokhtar, S. S. (2017). Linking attitude to actual purchase of herbal product in Malaysia: The moderating role of perceived risk. Journal of Asian Business Strategy, 6(2), 22-30. https://doi.org/10.18488/journal.1006/2016.6.2/1006.2.22.30 
Kealesitse, B., \& Kabama, I. O. (2012). Exploring the Influence of Quality and Safety on Consumers' Food Purchase Decisions in Botswana. International Journal of Business Administration, 3(2), 90-97. https://doi.org/10.5430/ijba.v3n2p90

Machrus, H., \& Purwono, U. (2010). Pengukuran Perilaku berdasarkan Theory of Planned Behaviour. Insan Media Psikologi, 12(01), 64-72. https://doi.org/10.1002/ejoc.201200111

Maichum, K., Parichatnon, S., \& Peng, K.-C. (2017). The Influence of Attitude, Knowledge and Quality on Purchase Intention towards Halal Food: A Case Study of Young NonMuslim Consumers in Thailand. IRA-International Journal of Management \& Social Sciences (ISSN 2455-2267), 6(3), 354. https://doi.org/10.21013/jmss.v6.n3.p3

Mohamed Omar, K., Kamariah Nik Mat, N., Ahmed Imhemed, G., \& Mahdi Ahamed Ali, F. (2012). The Direct Effects of Halal Product Actual Purchase Antecedents among the International Muslim Consumers. American Journal of Economics, 2(4), 87-92. https://doi.org/10.5923/j.economics.20120001.20

Nulufi, K., \& Murwartiningsih. (2015). Minat Beli Sebagai Mediasi Pengaruh Brand Image Dan Sikap Konsumen Terhadap Keputusan Pembelian Batik Di Pekalongan. Management Analysis Journal 4, 4(2), 129-141.

Pandey Akilesh, S. V. (2015). Role of consumer attitudes, beliefs and subjective norms as predictors of purchase behaviour: a study on personal care purchases. The Business \& Management Review, 5(4), 29-30.

Pangan, P. K., Kesehatan, K., Yang, N., Dan, D., Terhadap, H., \& Beli, N. (n.d.). Pengaruh keamanan pangan, kesadaran kesehatan, nilai yang dirasakan dan harga terhadap niat beli makanan cepat saji pada konsumen kfc di kota banda aceh. 3(2).

Prastiwi, S. K., \& Auliya, Z. F. (2016). Apakah Halal Awareness dapat meningkatkan Repurchase Intention? Do Halal Awareness Increasing Repurchase Intention? Ebbank, 7(2), 55-64.

Peter Paul, Olson Jerry. 2013. Perilaku konsumen dan strategi pemasaran. Jakarta:Salemba empat

Rachbini, W. (2018). The Relationship of Attitude, Subjective Norm , Perceived Behavioral Control on Halal Food Purchasing Behavior in Jakarta. IOSR Journal of Business and Management (IOSR-JBM) e-ISSN: 2278-487X, p-ISSN: 2319-7668., 20(1), 28-37. https://doi.org/10.9790/487X-2001082837

Ramdhani, N., Carver, C. S., Scheier, M. F., Segerstrom, S. C., Solberg Nes, L., Evans, D. R., ... Khatimah, H. (2011). Penyusunan Alat Pengukur Berbasis Theory of Planned Behavior. Buletin Psikologi, 4(1), 55-69. https://doi.org/10.22146/bpsi.11557

Wee, C. S., Ariff, M. S. Bin, Zakuan, N., \& Tajudin, M. N. (2012). Key Factors Affecting Consumer Purchase Intention a Study of Safe Vegetable in Ho Chi Minh City , Vietnam. Review of Integrative Business and Economics Research, 3(2), 378-397. 